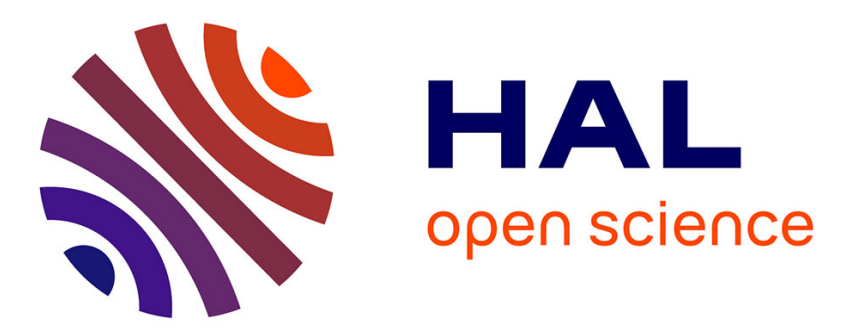

\title{
Back to the roots: how do seedlings of native tree species react to the competition by exotic species?
}

Heike Kawaletz, Inga Mölder, Peter Annighöfer, André Terwei, Stefan Zerbe, Christian Ammer

\section{- To cite this version:}

Heike Kawaletz, Inga Mölder, Peter Annighöfer, André Terwei, Stefan Zerbe, et al.. Back to the roots: how do seedlings of native tree species react to the competition by exotic species?. Annals of Forest Science, 2014, 71 (3), pp.337-347. 10.1007/s13595-013-0347-z . hal-01101538

\author{
HAL Id: hal-01101538 \\ https://hal.science/hal-01101538
}

Submitted on 8 Jan 2015

HAL is a multi-disciplinary open access archive for the deposit and dissemination of scientific research documents, whether they are published or not. The documents may come from teaching and research institutions in France or abroad, or from public or private research centers.
L'archive ouverte pluridisciplinaire HAL, est destinée au dépôt et à la diffusion de documents scientifiques de niveau recherche, publiés ou non, émanant des établissements d'enseignement et de recherche français ou étrangers, des laboratoires publics ou privés. 


\title{
Back to the roots: how do seedlings of native tree species react to the competition by exotic species?
}

\author{
Heike Kawaletz • Inga Mölder • Peter Annighöfer • \\ André Terwei • Stefan Zerbe • Christian Ammer
}

Received: 25 April 2013 /Accepted: 15 November 2013 /Published online: 6 December 2013

(C) INRA and Springer-Verlag France 2013

\begin{abstract}
- Context Identifying the traits of exotic species may explain their invasiveness and help control the negative impacts of these species on native ecosystems. In this study, we investigated root competition as an important driver for the competitiveness of two exotic tree species in the seedling stage.

- Aims In a pot experiment, carried out in Central Europe, we studied the effect of root competition of two exotic tree species (Prunus serotina Ehrh. and Robinia pseudoacacia L.) on biomass allocation of two native ones (Quercus robur L. and Carpinus betulus L.).

- Methods Seedlings of these species were exposed to intraand interspecific mixtures with and without the effect of root competition. For this, belowground plastic partitions were installed in the pots.

- Results Competition intensity in the pots increased over time, irrespective of mixture type. However, this increase was much higher for the native species if mixed with the exotic species compared to monocultures or inter-native
\end{abstract}

Handling Editor: Gilbert Aussenac

Contribution of the co-authors Heike Kawaletz: designing the experiment, writing the paper, running the data analysis

Inga Mölder: supervising the work, coordinating the research project

Peter Annighöfer, André Terwei: writing the paper

Stefan Zerbe, Christian Ammer: supervising the work, coordinating the research project

H. Kawaletz $(\bowtie) \cdot$ P. Annighöfer $\cdot$ C. Ammer

Department of Silviculture and Forest Ecology of the Temperate

Zones, University of Göttingen, Büsgenweg 1, 37077 Göttingen,

Germany

e-mail: hkawale@gwdg.de

I. Mölder

Energieagentur Region Göttingen e.V., Berliner Str. 2,

37073 Göttingen, Germany

A. Terwei $\cdot$ S. Zerbe

Faculty of Science and Technology, Free University

of Bozen-Bolzano, piazza Università 5, 39100 Bolzano, Italy mixtures. In addition to ontogeny, competition affected biomass allocation patterns. Under root competition by the exotic species, the native species preferentially allocated their biomass to the roots. A higher allocation to the roots was mainly achieved at the expense of leaf and branch biomass.

- Conclusion Root competition of P. serotina and $R$. pseudoacacia may be a reason for the lack of $Q$. robur and $C$. betulus in the seedling stage in natural environments where all four species occur.

Keywords Biomass allocation - Balanced growth hypothesis $\cdot$ Pot experiment $\cdot$ Prunus serotina $\cdot$ Robinia pseudoacacia

\section{Introduction}

In natural ecosystems, nutrients and other resources that are needed for tree growth, regeneration, and reproduction are usually limited. According to Goldberg (1990), a species is competitive if it combines two attributes: (1) being effective in acquiring resources to maintain its own fitness, i.e., reducing resource availability of competitors while increasing the own biomass, and (2) keeping growth and survival as high as possible if resource availability decreases. For both strategies, plasticity in biomass allocation is essential. Besides the effects of ontogeny, i.e., plant size, biomass allocation is therefore to a considerable amount driven by resource availability (Schall et al. 2012). As suggested by the balanced growth hypothesis (Shipley and Meziane 2002), under restricted resource availability, plants increase the efficiency in resource uptake and/or allocate more biomass to those compartments, which are involved in the acquisition of the primarily limiting resource. Numerous studies showed an effect of aboveground (shoot) competition on biomass partitioning (e.g., Horn 1971; Nilsson and Albrektson 1993; Feng et al. 2007). In case of strong shading, plants allocate more biomass to the aboveground 
organs, especially to the leaves, in order to maximize photosynthesis (van Hees 1997; Ammer 2003; Hofmann and Ammer 2008). Although belowground (root) competition is as important as aboveground interactions (Wilson 1988; Casper and Jackson 1997; Cahill 2003), there is less information on how tree species change biomass allocation patterns in response to belowground competition (Haase 2009). However, according to the balanced growth hypothesis, biomass will be allocated to the roots if nutrients or water becomes the limiting factor for growth (e.g., Ibrahim et al. 1998; Bloor et al. 2008; Kleczewski et al. 2012). By changing biomass allocation patterns, plants therefore respond to changes in resource availability, which may be interpreted as an adaptation to stress (e.g., Shipley and Meziane 2002; Delagrange et al. 2004; Curt et al. 2005). According to Weiner (2004), plasticity in biomass allocation is important for plant survival, e.g., under competitive situations. In environments of low soil water or nutrient availability, the proportion of root biomass may therefore be treated as a measure of competition pressure from neighboring plants (Aerts et al. 1991; Cahill 2003; Bloor et al. 2008).

In many ecosystems, invasive exotic species are able to alter the environmental conditions such as the nutrient and hydrologic cycle (Mack et al. 2000) and may negatively affect the abundance or survival of native species due to a higher biomass production (e.g., Morrison and Mauck 2007; Pyšek and Richardson 2008; Lamarque et al. 2011). The high biomass production in the early stages, indicating a strong competitiveness in the regeneration phase, leads to resource depletion, hampering the growth of neighboring plants.

The two North American tree species black cherry (Prunus serotina Ehrh.) and black locust (Robinia pseudoacacia L.) have managed to successfully spread throughout Europe. Both species are among the 18 most invasive terrestrial plant species (DAISIE Project 2009). They are considered to be under the most aggressive exotic tree species in European forests and are regarded as strong competitors of native tree species (e.g., Kleinbauer et al. 2010; Vanhellemont et al. 2010). P. serotina was one of the first North American tree species that was introduced to Europe (Starfinger et al. 2003). It is able to alter biodiversity if it occurs in monospecific stands that impede native tree regeneration (Closset-Kopp et al. 2007). Due to its ability to fix nitrogen, $R$. pseudoacacia especially is a threat for the identity and integrity of nutrientpoor sites where it can change soil conditions and alter species compositions (Rice et al. 2004; Motta et al. 2009; Annighöfer et al. 2012). On several sites in Europe, $P$. serotina and $R$. pseudoacacia negatively affect the regeneration of cooccurring native species. An example is the low abundance of Quercus robur L. and Carpinus betulus L. in North Italian floodplain forests (Annighöfer et al. 2012; Terwei et al. 2013). In Central Europe, $Q$. robur is one of the most frequent deciduous forest tree species. It has a high demand for light and is not able to successfully compete with species casting deep shade. $C$. betulus is a late successional, shade-tolerant species and is often associated with Q. robur in QuercoCarpinetum forests that can be found on the most fertile soils in temperate Europe (Ellenberg 1988).

Actually, in a pot experiment containing mixtures of exotic $P$. serotina and $R$. pseudoacacia and the two native species $Q$. robur and $C$. betulus, strongly changed biomass production was observed (Kawaletz et al. 2013). In the regarding experiment, the competition and growth response of the four species in monocultures and mixtures were studied under controlled conditions. Whereas biomass production of the species in different inter- and intraspecific competitive situations was the main focus of a previous article (Kawaletz et al. 2013), biomass allocation pattern is addressed in the present study. We tested the following hypotheses: (1) competition by exotic $P$. serotina and R. pseudoacacia on native $Q$. robur and $C$. betulus under open field conditions is much stronger than that of intraspecific or inter-native interference and (2) the proportion of root biomass of a seedling increases with increasing root competition intensity.

\section{Methods}

\subsection{Experimental setup}

A controlled pot experiment was conducted under outdoors conditions in Göttingen, Germany (see also Kawaletz et al. 2013). The experimental site was located at $170 \mathrm{~m}$ above sea level. The climate is temperate with an average annual precipitation of $644.9 \mathrm{~mm}$ and most of the rain falling in June $(81.3 \mathrm{~mm})$. The average monthly temperature ranges from 4.8 to $13{ }^{\circ} \mathrm{C}$, with a mean annual temperature of about $8.7^{\circ} \mathrm{C}$ (Wetterstation Göttingen 2013).

Four tree species were used for the pot experiment: pedunculate oak ( $Q$. robur $)$ and hornbeam (C. betulus) were chosen as native species; black cherry ( $P$. serotina) and black locust (R. pseudoacacia) represented the exotic species in the experiment. The seedlings of each tree species were obtained from a nursery in Germany (Münchehof, Lower Saxony) to minimize transport-induced damages. In spring 2010, the 1-year-old seedlings were planted in pots with a volume of 651 (diameter, $54 \mathrm{~cm}$; height, $33 \mathrm{~cm}$ ). Prior to planting, each pot was filled with $5 \mathrm{~cm}$ coarse gravel to ensure drainage and with fertilized potting soil (Einheitserde-und Humuswerke, Gebr. Patzer GmbH \& Co. KG, Sinntal-Jossa/Germany, type Eurohum $\mathrm{CRH})$. The potting soil was used to ensure homogeneous substrate and nutrient conditions in every pot. The potting soil was coarsely structured and mainly contained peat and humus with a small fraction of sand and clay. The fertilizer content within the soil was $140 \mathrm{mg} / \mathrm{l}$ for nitrogen and phosphor and $200 \mathrm{mg} / \mathrm{l}$ for potassium. The tree seedlings were watered as 
needed, with all pots receiving the same amount of water. Excess water drained through holes in the bottom of the pots. During winter, the pots were arranged close to each other and embedded in foliar litter to prevent frost damage to the roots. All pots were placed randomly on the area to avoid edge effects, i.e., differences in light and temperature conditions, etc. The distance between the pots was $1 \mathrm{~m}$, which ensured sufficient light supply for each plant. The plants were examined during two growing periods, beginning in April 2010 and ending in October 2011. Since Q. robur is a shade-intolerant species and we did not want to reduce its competiveness by shade, the study was carried out under full light. The growing conditions for all individuals and all species were similar.

Four seedlings were planted per pot and arranged in ten different species mixtures, of which four were monocultures and six were species mixtures. Every mixture consisted of not more than two species. The following six mixtures were used: (1) Q. robur with C. betulus, (2) R. pseudoacacia with $P$. serotina, (3) $Q$. robur with $R$. pseudoacacia, (4) $Q$. robur with $P$. serotina, (5) C. betulus with $R$. pseudoacacia, and (6) $C$. betulus with $P$. serotina. There were 36 replicates for the monoculture pots and 60 replicates for each of the six species mixtures. Pots with dead seedlings had to be excluded from further analyses since even only one dead plant per pot would have changed the competitive situation compared to those pots containing four plants. Mortality reduced the number of pots from 504 to 201 (see number of individuals per treatment in Table 1).

\subsection{Competition treatments}

A modified "divided pot technique" was used to study the different effects of belowground (root) and aboveground (shoot) competition (Donald 1958; McPhee and Aarssen 2001). The pots were assigned to either root competition, shoot competition, or full competition (i.e., root and shoot competition) treatment. Pots without competition (no competition treatment) were excluded from the analysis because of insufficient data due to high mortality. The different competition treatments were achieved by installing aboveground and belowground partitions allowing only root or shoot competition, respectively. The above- and belowground partitions were made of white rigid PVC sheets since white aboveground partitions reflected the sunlight and thus leveled the light conditions on all four sections of the pot. However, in our experiment, shoot competition had no significant effect on tree growth within a mixture type (data not shown). We therefore pooled the two treatments in which the seedlings were exposed to root competition (i.e., root and full competition) and compared them with the treatment without root competition (i.e., shoot competition treatment). Therefore, "root competition" (RC) was contrasted with "no root competition" (nRC).

\subsection{Measurements}

Seedling diameter ( $3 \mathrm{~cm}$ above ground) and height were measured for all seedlings at the start of the experiment and after two vegetation periods to calculate relative increment. To ensure an identical measuring point for each individual in every measuring campaign, the position was marked in 2010. At the end of the experiment, all pots with four living plants were harvested, resulting in a total of $n=804$ trees, of which $n=246$ were $Q$. robur, $n=240$ were $C$. betulus, $n=188$ were $R$. pseudoacacia , and $n=130$ were $P$. serotina seedlings (Table 1). The biomass of every tree seedling was assigned to stems, branches, roots, and leaves. The dry weight with an accuracy of $0.001 \mathrm{~g}$ was determined separately after drying all biomass compartments for 3 days at $70{ }^{\circ} \mathrm{C}$ in a temperaturecontrolled oven until a constant weight was achieved.

\subsection{Data analysis}

All statistical tests and the preparation of graphs were performed using the free software environment $\mathrm{R}$ ( $\mathrm{R}$ Development Core Team 2012). To avoid pseudoreplication, data were analyzed on the species level, i.e., data were averaged for the individuals of a given species per pot. Additionally, we performed a variance component analysis to ensure that pot effects can be excluded.

The Shapiro-Wilk normality test was used to analyze data distribution. To assess homoscedasticity, we used Levene's test. If data showed a normal distribution and if the variances were homogenous, we used an analysis of variance (ANOVA) and Tukey's range test to find significant differences between groups. If data could not be assumed to be normally distributed and/or did not show homoscedasticity, we used the Kruskal-Wallis test and applied pairwise comparisons with the Wilcoxon rank sum test. All tests comparing groups were two-sided.

To show how competition intensity changed over time in the different species mixtures, we calculated Lorimer's competition index for all trees of a pot (Lorimer 1983).

Lorimer's competition index $x_{i}=\sum_{j=1}^{n} d_{j} / d_{i}$

where $n$ is the number of competitors (in our case, $n=3$ ), $d_{j}$ is the diameter of the competitor $j$ (in millimeters), and $d_{i}$ is the diameter of the target tree $i$ (in millimeters) at a given time (in our case, start and end of the experiment). The competition index was averaged per species and pot.

The effect of factor levels (i.e., different species mixtures) on the biomass allocation to plant compartments were analyzed for both competition treatments individually using ANCOVA with tree size as covariate (model: factor + tree size) since plant biomass allocation is size-dependent (Schall et al. 
Table 1 Mean relative increment in seedling diameter and height \pm SE and number of plants per treatment $(n)$

\begin{tabular}{|c|c|c|c|c|c|c|}
\hline \multirow[t]{2}{*}{ Species } & & & \multicolumn{4}{|l|}{ Mixed with } \\
\hline & & & Quercus robur & Carpinus betulus & Robinia pseudoacacia & Prunus serotina \\
\hline \multirow[t]{10}{*}{ Quercus robur } & \multirow[t]{4}{*}{ Diameter } & \multirow[t]{2}{*}{$\mathrm{RC}$} & $1.31^{\mathrm{a}}$ & $1.30^{\mathrm{a}}$ & $0.52^{\mathrm{b}}$ & $0.33^{\mathrm{b}}$ \\
\hline & & & \pm 0.09 & \pm 0.11 & \pm 0.09 & \pm 0.06 \\
\hline & & \multirow[t]{2}{*}{$\mathrm{nRC}$} & $1.47^{\mathrm{a}}$ & $1.17^{\mathrm{ab}}$ & $0.74^{\mathrm{bc}}$ & $0.33^{\mathrm{c}}$ \\
\hline & & & \pm 0.17 & \pm 0.11 & \pm 0.08 & \pm 0.08 \\
\hline & \multirow[t]{4}{*}{ Height } & \multirow[t]{2}{*}{$\mathrm{RC}$} & $1.66^{\mathrm{a}}$ & $1.63^{\mathrm{a}}$ & $0.44^{\mathrm{b}}$ & $0.45^{\mathrm{b}}$ \\
\hline & & & \pm 0.14 & \pm 0.17 & \pm 0.08 & \pm 0.47 \\
\hline & & \multirow[t]{2}{*}{$\mathrm{nRC}$} & $1.51^{\mathrm{a}}$ & $1.71^{\mathrm{a}}$ & $0.45^{\mathrm{b}}$ & $0.29^{b}$ \\
\hline & & & \pm 0.25 & \pm 0.21 & \pm 0.12 & \pm 0.10 \\
\hline & \multirow[t]{2}{*}{$n$} & $\mathrm{RC}$ & 72 & 40 & 28 & 22 \\
\hline & & $\mathrm{nRC}$ & 24 & 32 & 18 & 10 \\
\hline \multirow[t]{10}{*}{ Carpinus betulus } & \multirow[t]{4}{*}{ Diameter } & \multirow[t]{2}{*}{$\mathrm{RC}$} & $2.79^{\mathrm{a}}$ & $2.58^{\mathrm{a}}$ & $1.02^{b}$ & $1.09^{\mathrm{b}}$ \\
\hline & & & \pm 0.17 & \pm 0.16 & \pm 0.13 & \pm 0.13 \\
\hline & & \multirow[t]{2}{*}{$\mathrm{nRC}$} & $3.08^{\mathrm{a}}$ & $2.75^{\mathrm{a}}$ & $1.31^{\mathrm{b}}$ & $2.35^{\mathrm{ab}}$ \\
\hline & & & \pm 0.20 & \pm 0.24 & \pm 0.11 & \pm 0.41 \\
\hline & \multirow[t]{4}{*}{ Height } & \multirow[t]{2}{*}{$\mathrm{RC}$} & $4.79^{\mathrm{a}}$ & $4.18^{\mathrm{a}}$ & $1.87^{\mathrm{b}}$ & $1.51^{\mathrm{b}}$ \\
\hline & & & \pm 0.34 & \pm 0.23 & \pm 0.29 & \pm 0.25 \\
\hline & & \multirow[t]{2}{*}{$\mathrm{nRC}$} & $4.55^{\mathrm{a}}$ & $4.75^{\mathrm{a}}$ & $2.14^{\mathrm{b}}$ & $2.54^{\mathrm{ab}}$ \\
\hline & & & \pm 0.38 & \pm 0.39 & \pm 0.26 & \pm 0.52 \\
\hline & \multirow[t]{2}{*}{$n$} & $\mathrm{RC}$ & 40 & 60 & 32 & 24 \\
\hline & & $\mathrm{nRC}$ & 32 & 32 & 14 & 6 \\
\hline \multirow[t]{10}{*}{ Robinia pseudoacacia } & \multirow[t]{4}{*}{ Diameter } & \multirow[t]{2}{*}{$\mathrm{RC}$} & $3.28^{\mathrm{a}}$ & $3.31^{\mathrm{a}}$ & $2.25^{\mathrm{b}}$ & $2.46^{\mathrm{ab}}$ \\
\hline & & & \pm 0.29 & \pm 0.26 & \pm 0.16 & \pm 0.20 \\
\hline & & \multirow[t]{2}{*}{$\mathrm{nRC}$} & $2.91^{\mathrm{a}}$ & $2.97^{\mathrm{a}}$ & $2.46^{\mathrm{a}}$ & $2.14^{\mathrm{a}}$ \\
\hline & & & \pm 0.22 & \pm 0.23 & \pm 0.12 & \pm 0.22 \\
\hline & \multirow[t]{4}{*}{ Height } & \multirow[t]{2}{*}{$\mathrm{RC}$} & $5.83^{\mathrm{a}}$ & $6.23^{\mathrm{a}}$ & $3.93^{\mathrm{a}}$ & $6.52^{\mathrm{a}}$ \\
\hline & & & \pm 1.27 & \pm 1.94 & \pm 0.86 & \pm 2.62 \\
\hline & & \multirow[t]{2}{*}{$\mathrm{nRC}$} & $11.59^{\mathrm{a}}$ & $8.89^{\mathrm{a}}$ & $6.54^{\mathrm{b}}$ & $4.95^{b}$ \\
\hline & & & \pm 3.37 & \pm 2.60 & \pm 1.92 & \pm 1.65 \\
\hline & $n$ & $\mathrm{RC}$ & 28 & 32 & 44 & 16 \\
\hline & & $\mathrm{nRC}$ & 18 & 14 & 28 & 8 \\
\hline Prunus serotina & Diameter & $\mathrm{RC}$ & $5.58^{\mathrm{a}}$ & $5.62^{\mathrm{a}}$ & $4.37^{b}$ & $4.54^{b}$ \\
\hline & & & \pm 0.26 & \pm 0.23 & \pm 0.29 & \pm 0.30 \\
\hline & & $\mathrm{nRC}$ & $5.46^{\mathrm{a}}$ & $4.90^{\mathrm{ab}}$ & $4.03^{b}$ & $4.51^{\mathrm{b}}$ \\
\hline & & & \pm 0.29 & \pm 0.49 & \pm 0.14 & \pm 0.18 \\
\hline & Height & $\mathrm{RC}$ & $1.81^{\mathrm{a}}$ & $1.93^{\mathrm{a}}$ & $1.27^{\mathrm{b}}$ & $1.71^{\mathrm{a}}$ \\
\hline & & & \pm 0.17 & \pm 0.22 & \pm 0.13 & \pm 0.16 \\
\hline & & $\mathrm{nRC}$ & $1.63^{\mathrm{a}}$ & $1.53^{\mathrm{a}}$ & $1.09^{\mathrm{a}}$ & $1.88^{\mathrm{a}}$ \\
\hline & & & \pm 0.16 & \pm 0.12 & \pm 0.08 & \pm 0.38 \\
\hline & $n$ & $\mathrm{RC}$ & 22 & 24 & 16 & 20 \\
\hline & & $\mathrm{nRC}$ & 10 & 6 & 8 & 24 \\
\hline
\end{tabular}

Data are shown for monocultures and mixtures with $(\mathrm{RC})$ or without $(\mathrm{nRC})$ root competition. Different lowercase letters indicate significant differences between the species mixtures in both competition treatments (Wilcoxon rank sum test, two-sided: $P<0.05$ )

2012). Differences between factor levels were determined using Tukey's HSD test for linear models (R package multcomp: $P<0.05)$. The effect of experimental factors on the relationship between root and total biomass was analyzed using linear models also taking the interaction of factor levels and size (total biomass) into account. The minimal adequate model was determined using the backward model simplification method ( $P<0.05$; Crawley 2007). 


\section{Results}

\subsection{Mortality}

The mortality rate was significantly higher for $P$. serotina (45\%) and $R$. pseudoacacia (24\%) than for $Q$. robur $(13 \%)$ and $C$. betulus $\left(10 \%\right.$; $\chi^{2}$ test: $\left.P<0.001\right)$. However, there were neither significant differences between the competition treatments nor between the species mixtures (data not shown). The majority of all dead tree seedlings died during the first few weeks after planting.

\subsection{Relative increment in seedling diameter and height}

The relative increment in seedling diameter and height differed considerably between all species after two vegetation periods (Table 1). In general, relative diameter increment averaged for all species mixtures and competition treatments was lowest for $Q$. robur (1.06), followed by C. betulus (2.27) and $R$. pseudoacacia (2.79), and was significantly highest for P. serotina (4.98). Interestingly, the mean relative height increment of $P$. serotina was considerably lower compared to $C$. betulus and $R$. pseudoacacia. For both native species, the relative increment in diameter and height were significantly lower in mixtures with one of the exotic species than in monocultures or mixtures with each other. The relative increments in the diameter and height of $R$. pseudoacacia and P. serotina were higher if mixed with one of the native species than in monocultures. The highest final

\section{Quercus robur}

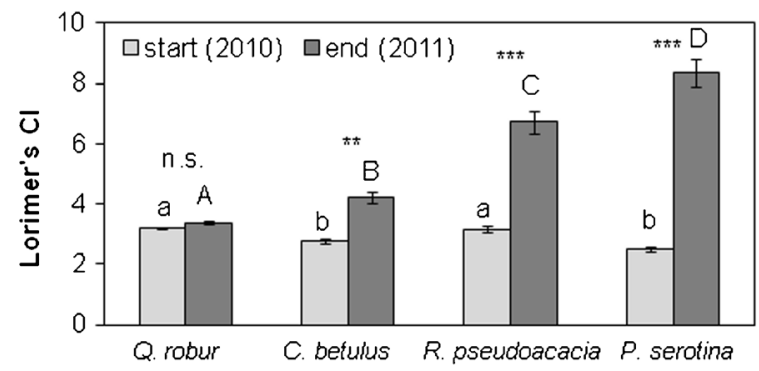

Robinia pseudoacacia

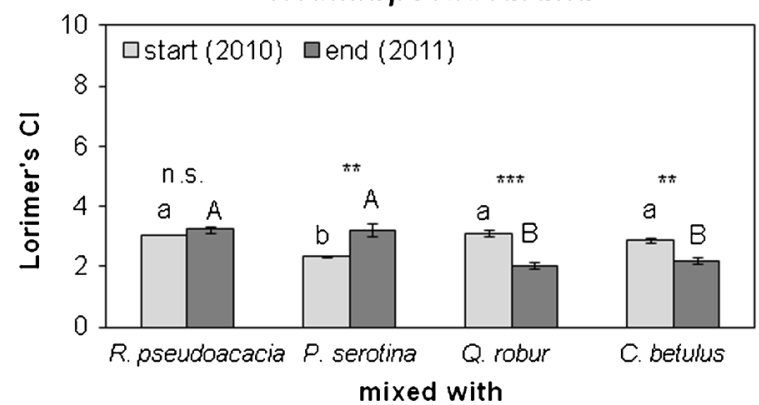

Fig. 1 Bar plots show Lorimer's competition index at the start (April 2010) and at the end (October 2011) of the pot experiment (averaged for each species per pot). Data are given for the different tree species in monoculture and species mixtures averaged for the two competition treatments (RC and $\mathrm{nRC}$ ). Asterisks show the significant differences diameters were reached by $P$. serotina in a mixture with one of the native species $(24.96 \mathrm{~mm}$ averaged for both competition treatments; data not shown). Mean stem height was highest for $R$. pseudoacacia when growing together with one of the native species $(155.81 \mathrm{~cm})$. In contrast, $Q$. robur had the lowest averaged diameter and height when mixed with $R$. pseudoacacia or $P$. serotina (diameter, $8.34 \mathrm{~mm}$; height, $37.19 \mathrm{~cm}$ ). For $C$. betulus, but not for $Q$. robur, the relative increments in diameter and height were higher in the $\mathrm{nRC}$ treatment when root competition with one of the exotic species was excluded (Table 1).

\subsection{Competition intensity}

Competition intensity, as calculated using Lorimer's competition index, did not differ significantly between the four species at the start of the experiment. In comparison with $C$. betulus and $P$. serotina, the initial tree dimensions were higher for $Q$. robur and R. pseudoacacia, thus leading to a lower Lorimer's competition index (Fig. 1). However, at the end of the experiment, it was about twice as high for $Q$. robur and $C$. betulus compared to $R$. pseudoacacia and $P$. serotina. Both exotic species exerted the strongest competitive pressure on both native species. For $Q$. robur, the mean Lorimer's competition index was significantly higher in a mixture with P. serotina (8.36) than with $R$. pseudoacacia (6.73). For $C$. betulus, there was no significant difference when growing with $R$. pseudoacacia or P. serotina. For both exotic species, competition intensity was significantly higher in monoculture or in a mixture with the other exotic

\section{Carpinus betulus}

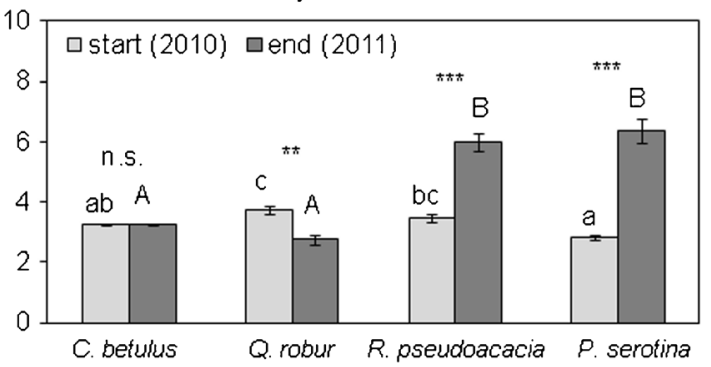

Prunus serotina

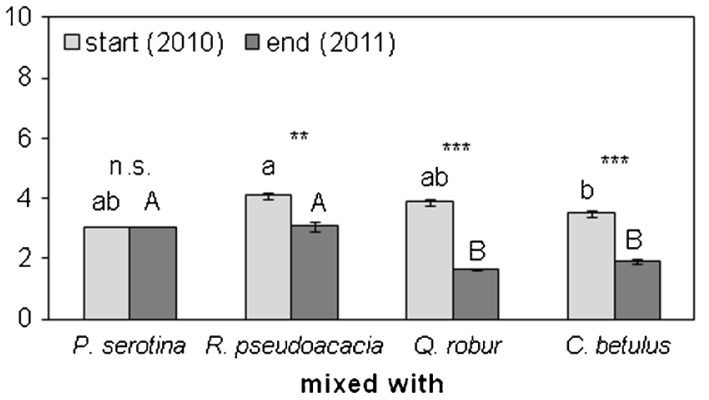

between start and end of the experiment for each species mixture (ANOVA: $* * * P<0.001, * * P<0.01, * P<0.05 ;$ n.s. not significant). Different letters above each bar indicate significant differences between species mixtures at the start (small letters) and at the end (capital letters) of the experiment (ANOVA: $P<0.05$ ) 
Table 2 Mean biomass (in grams) of the different plant compartments (averaged for each species per pot)

\begin{tabular}{|c|c|c|c|c|c|c|}
\hline \multirow[t]{2}{*}{ Species } & \multicolumn{2}{|c|}{ Biomass compartment } & \multicolumn{4}{|l|}{ Mixed with } \\
\hline & & & Quercus robur & Carpinus betulus & Robinia pseudoacacia & Prunus serotina \\
\hline \multirow[t]{12}{*}{ Quercus robur } & \multirow[t]{2}{*}{ Total tree } & $\mathrm{RC}$ & $131.69^{\mathrm{a}}$ & $114.82^{\mathrm{a}}$ & $33.87^{\mathrm{b}}$ & $27.65^{b}$ \\
\hline & & $\mathrm{nRC}$ & $116.33^{\mathrm{a}}$ & $120.33^{\mathrm{a}}$ & $41.56^{b}$ & $33.03^{b}$ \\
\hline & \multirow[t]{2}{*}{ Belowground } & $\mathrm{RC}$ & $64.10^{\mathrm{a}}$ & $58.81^{\mathrm{a}}$ & $19.17^{b}$ & $16.96^{\mathrm{b}}$ \\
\hline & & $\mathrm{nRC}$ & $58.24^{\mathrm{a}}$ & $57.30^{\mathrm{a}}$ & $25.44^{\mathrm{b}}$ & $17.82^{b}$ \\
\hline & \multirow[t]{2}{*}{ Aboveground } & $\mathrm{RC}$ & $67.59^{\mathrm{a}}$ & $56.01^{\mathrm{a}}$ & $14.70^{\mathrm{b}}$ & $10.69^{b}$ \\
\hline & & $\mathrm{nRC}$ & $58.09^{\mathrm{a}}$ & $63.03^{\mathrm{a}}$ & $19.11^{\mathrm{b}}$ & $15.21^{\mathrm{b}}$ \\
\hline & \multirow[t]{2}{*}{ Stem } & $\mathrm{RC}$ & $32.06^{\mathrm{a}}$ & $26.62^{a}$ & $5.56^{\mathrm{b}}$ & $5.24^{\mathrm{b}}$ \\
\hline & & $\mathrm{nRC}$ & $23.42^{\mathrm{a}}$ & $27.13^{\mathrm{a}}$ & $8.51^{\mathrm{b}}$ & $5.01^{\mathrm{b}}$ \\
\hline & \multirow[t]{2}{*}{ Branch } & $\mathrm{RC}$ & $12.14^{\mathrm{a}}$ & $10.22^{\mathrm{a}}$ & $1.37^{\mathrm{b}}$ & $2.07^{\mathrm{b}}$ \\
\hline & & $\mathrm{nRC}$ & $11.15^{\mathrm{a}}$ & $12.70^{\mathrm{a}}$ & $2.90^{\mathrm{b}}$ & $6.08^{a b}$ \\
\hline & \multirow[t]{2}{*}{ Leaf } & $\mathrm{RC}$ & $23.39^{\mathrm{a}}$ & $19.17^{\mathrm{a}}$ & $7.77^{\mathrm{b}}$ & $3.38^{\mathrm{b}}$ \\
\hline & & $\mathrm{nRC}$ & $23.52^{\mathrm{a}}$ & $23.19^{\mathrm{a}}$ & $7.70^{\mathrm{b}}$ & $4.12^{b}$ \\
\hline \multirow[t]{12}{*}{ Carpinus betulus } & \multirow[t]{2}{*}{ Total tree } & $\mathrm{RC}$ & $192.89^{\mathrm{a}}$ & $142.12^{\mathrm{a}}$ & $30.46^{\mathrm{b}}$ & $31.69^{b}$ \\
\hline & & $\mathrm{nRC}$ & $187.19^{\mathrm{a}}$ & $141.34^{b}$ & $51.71^{\mathrm{c}}$ & $96.53^{b c}$ \\
\hline & \multirow[t]{2}{*}{ Belowground } & $\mathrm{RC}$ & $68.34^{\mathrm{a}}$ & $48.57^{\mathrm{b}}$ & $12.43^{\mathrm{c}}$ & $14.02^{c}$ \\
\hline & & $\mathrm{nRC}$ & $72.02^{\mathrm{a}}$ & $51.84^{b}$ & $22.21^{\mathrm{c}}$ & $40.72^{b c}$ \\
\hline & \multirow[t]{2}{*}{ Aboveground } & $\mathrm{RC}$ & $124.55^{\mathrm{a}}$ & $93.55^{\mathrm{a}}$ & $18.03^{b}$ & $17.67^{b}$ \\
\hline & & $\mathrm{nRC}$ & $115.16^{\mathrm{a}}$ & $89.51^{\mathrm{ab}}$ & $29.50^{\mathrm{c}}$ & $55.81^{\mathrm{bc}}$ \\
\hline & \multirow[t]{2}{*}{ Stem } & $\mathrm{RC}$ & $55.07^{\mathrm{a}}$ & $39.62^{\mathrm{a}}$ & $8.72^{b}$ & $8.13^{b}$ \\
\hline & & $\mathrm{nRC}$ & $47.27^{\mathrm{a}}$ & $35.57^{\mathrm{ab}}$ & $12.51^{\mathrm{c}}$ & $23.71^{b c}$ \\
\hline & \multirow[t]{2}{*}{ Branch } & $\mathrm{RC}$ & $28.70^{\mathrm{a}}$ & $23.80^{\mathrm{a}}$ & $3.46^{\mathrm{b}}$ & $4.19^{b}$ \\
\hline & & $\mathrm{nRC}$ & $31.13^{\mathrm{a}}$ & $24.04^{\mathrm{a}}$ & $6.55^{\mathrm{b}}$ & $13.03^{\mathrm{ab}}$ \\
\hline & \multirow[t]{2}{*}{ Leaf } & $\mathrm{RC}$ & $40.78^{\mathrm{a}}$ & $30.13^{\mathrm{a}}$ & $5.85^{\mathrm{b}}$ & $5.35^{\mathrm{b}}$ \\
\hline & & $\mathrm{nRC}$ & $36.76^{\mathrm{a}}$ & $29.90^{\mathrm{ab}}$ & $10.44^{\mathrm{c}}$ & $19.07^{b c}$ \\
\hline \multirow[t]{12}{*}{ Robinia pseudoacacia } & \multirow[t]{2}{*}{ Total tree } & $\mathrm{RC}$ & $396.39^{a}$ & $399.84^{\mathrm{a}}$ & $253.70^{b}$ & $251.24^{b}$ \\
\hline & & $\mathrm{nRC}$ & $360.60^{\mathrm{a}}$ & $412.29^{\mathrm{a}}$ & $192.68^{b}$ & $236.82^{\mathrm{ab}}$ \\
\hline & \multirow[t]{2}{*}{ Belowground } & $\mathrm{RC}$ & $115.48^{\mathrm{a}}$ & $117.13^{\mathrm{a}}$ & $73.38^{b}$ & $88.20^{\mathrm{b}}$ \\
\hline & & $\mathrm{nRC}$ & $119.13^{\mathrm{a}}$ & $133.20^{\mathrm{a}}$ & $53.63^{\mathrm{b}}$ & $73.66^{\mathrm{ab}}$ \\
\hline & \multirow[t]{2}{*}{ Aboveground } & $\mathrm{RC}$ & $280.91^{\mathrm{ab}}$ & $282.71^{\mathrm{a}}$ & $180.32^{\mathrm{ab}}$ & $163.04^{\mathrm{b}}$ \\
\hline & & $\mathrm{nRC}$ & $241.47^{\mathrm{a}}$ & $279.09^{\mathrm{a}}$ & $139.05^{\mathrm{b}}$ & $163.15^{\mathrm{ab}}$ \\
\hline & Stem & $\mathrm{RC}$ & $120.52^{\mathrm{a}}$ & $119.68^{a}$ & $75.92^{b}$ & $69.16^{\mathrm{b}}$ \\
\hline & & $\mathrm{nRC}$ & $117.14^{\mathrm{a}}$ & $115.76^{\mathrm{a}}$ & $63.95^{\mathrm{b}}$ & $62.85^{\mathrm{b}}$ \\
\hline & Branch & $\mathrm{RC}$ & $72.54^{\mathrm{ab}}$ & $77.21^{\mathrm{a}}$ & $46.24^{\mathrm{ab}}$ & $37.27^{b}$ \\
\hline & & $\mathrm{nRC}$ & $57.34^{\mathrm{ab}}$ & $69.31^{\mathrm{b}}$ & $31.05^{\mathrm{c}}$ & $34.70^{\mathrm{ac}}$ \\
\hline & Leaf & $\mathrm{RC}$ & $87.85^{\mathrm{a}}$ & $85.82^{\mathrm{a}}$ & $58.16^{\mathrm{a}}$ & $56.61^{\mathrm{a}}$ \\
\hline & & $\mathrm{nRC}$ & $66.99^{\mathrm{ab}}$ & $94.02^{b}$ & $44.04^{c}$ & $65.60^{\mathrm{ac}}$ \\
\hline Prunus serotina & Total tree & $\mathrm{RC}$ & $713.03^{\mathrm{a}}$ & $657.35^{\mathrm{ab}}$ & $299.3^{b}$ & $517.57^{\mathrm{ab}}$ \\
\hline & & $\mathrm{nRC}$ & $603.13^{\mathrm{a}}$ & $491.55^{\mathrm{ab}}$ & $359.53^{b}$ & $435.16^{\mathrm{ab}}$ \\
\hline & Belowground & $\mathrm{RC}$ & $270.33^{a}$ & $269.17^{\mathrm{ab}}$ & $114.18^{b}$ & $230.22^{\mathrm{ab}}$ \\
\hline & & $\mathrm{nRC}$ & $263.94^{\mathrm{a}}$ & $208.77^{\mathrm{ab}}$ & $159.18^{b}$ & $187.99^{b}$ \\
\hline & Aboveground & $\mathrm{RC}$ & $442.70^{\mathrm{a}}$ & $388.18^{\mathrm{ab}}$ & $185.13^{b}$ & $287.35^{\mathrm{ab}}$ \\
\hline & & $\mathrm{nRC}$ & $339.19^{a}$ & $282.78^{a b}$ & $200.35^{b}$ & $247.17^{\mathrm{ab}}$ \\
\hline & Stem & $\mathrm{RC}$ & $155.43^{\mathrm{a}}$ & $133.54^{\mathrm{ab}}$ & $64.10^{\mathrm{b}}$ & $114.32^{\mathrm{ab}}$ \\
\hline & & $\mathrm{nRC}$ & $113.93^{\mathrm{a}}$ & $106.16^{\mathrm{ab}}$ & $79.06^{b}$ & $88.66^{a b}$ \\
\hline & Branch & $\mathrm{RC}$ & $130.06^{\mathrm{a}}$ & $114.83^{\mathrm{ab}}$ & $41.50^{b}$ & $81.50^{a b}$ \\
\hline & & $\mathrm{nRC}$ & $100.14^{a}$ & $63.33^{\mathrm{ab}}$ & $48.28^{b}$ & $67.65^{a b}$ \\
\hline & Leaf & $\mathrm{RC}$ & $157.21^{\mathrm{a}}$ & $139.81^{\mathrm{ab}}$ & $79.53^{b}$ & $91.53^{\mathrm{ab}}$ \\
\hline
\end{tabular}


Table 2 (continued)

\begin{tabular}{|c|c|c|c|c|c|}
\hline \multirow[t]{2}{*}{ Species } & \multirow[t]{2}{*}{ Biomass compartment } & \multicolumn{4}{|l|}{ Mixed with } \\
\hline & & Quercus robur & Carpinus betulus & Robinia pseudoacacia & Prunus serotina \\
\hline & $\mathrm{nRC}$ & $125.12^{\mathrm{a}}$ & $113.29^{\mathrm{ab}}$ & $73.00^{\mathrm{b}}$ & $86.97^{\mathrm{ab}}$ \\
\hline
\end{tabular}

Data are shown for monocultures and mixtures with $(\mathrm{RC})$ or without (nRC) root competition. Different lowercase letters indicate significant differences between the species mixtures in both competition treatments (Wilcoxon rank sum test, two-sided: $P<0.05$ )

species compared to the mixtures with one of the native species at the end of the experiment.

A significant effect of the competition treatment ( $\mathrm{RC}$ and $\mathrm{nRC}$ ) could only be found for native species in mixtures with one of the exotic species. In these cases, Lorimer's competition index was higher in the $\mathrm{RC}$ than in the $\mathrm{nRC}$ treatment. However, for most species combinations, there were no significant differences between the two competition treatments. Therefore, both competition treatments were pooled to simplify Fig. 1.

\subsection{Biomass partitioning}

Independent of the applied competition treatment ( $\mathrm{RC}$ and $\mathrm{nRC}$ ), the strong competition pressure of both exotic species reduced the biomass of $Q$. robur and $C$. betulus due to the significantly higher biomasses of $R$. pseudoacacia and $P$. serotina (Table 2). All biomass compartments of $P$. serotina were highest in the mixture with $Q$. robur. In addition to the mixture effect, the influence of belowground competition (RC) led to a further biomass reduction for the native species in the mixture with P. serotina and R. pseudoacacia (Table 2 and Fig. 2, RC).

The proportions of the four biomass compartments differed between monocultures and species mixtures (Table 2). For $Q$. robur, biomass reduction of all compartments except for branch biomass was highest in the mixture with P. serotina, whereas $R$. pseudoacacia had the strongest negative effect on all biomass compartments of $C$. betulus. On average, for both native species, absolute biomass reduction was approximately $10 \%$ higher for the aboveground compartments than for the roots. For $Q$. robur, the strongest reduction was found for leaf biomass, which was reduced by $83 \%$ in the mixture with $P$. serotina. Branch biomass of $C$. betulus was reduced most strongly in both mixtures with exotic species $(-79 \%$ if mixed with $R$. pseudoacacia and $-64 \%$ if mixed with P. serotina, respectively). For P. serotina, the biomass of all compartments was higher in combination with $Q$. robur compared to mixtures with $R$. pseudoacacia. The biomass increment of $R$. pseudoacacia was higher for the roots than for the aboveground compartments, whereas for P. serotina it was the other way around. $Q$. robur had a most beneficial effect on the leaf
(59 \%) and branch biomass (58 \%) of P. serotina. When growing together in one pot, both exotic species influenced each other negatively. On the one hand, $R$. pseudoacacia slightly reduced the branch and root biomass of P. serotina (reductions of 39 and $33 \%$, respectively) in comparison with monocultures of $P$. serotina. On the other hand, if mixed with $P$. serotina, $R$. pseudoacacia showed reduced stem and branch biomass (reductions of 5 and $4 \%$, respectively).

Biomass partitioning was influenced by tree size, but not for all compartments (Table 3). Mixture type and competition treatment were found to affect biomass allocation as well (Fig. 2 and Tables 2 and 3). In the $\mathrm{RC}$ treatment, biomass partitioning between above- and belowground components was affected by mixture for all species (Fig. 2, RC). Both native species had a higher proportion of root biomass when exposed to interspecific root competition with $R$. pseudoacacia and P. serotina (Table 3). Accordingly, the averaged root-to-shoot ratio for both competition treatments of Q. robur was higher in the mixture with one of the exotic species (1.32 and 1.38 in the mixture with $R$. pseudoacacia and P. serotina, respectively) compared to monoculture $(0.98)$ or if mixed with C. betulus (0.98; Table 2). In the RC treatment, the proportion of root biomass of $R$. pseudoacacia was highest in the mixture with $P$. serotina, but compared to monoculture, it did not change significantly in the mixture with $C$. betulus and $Q$. robur (Fig. 2, RC, and Table 3). Biomass allocation to the roots of $P$. serotina was highest in the mixture with $R$. pseudoacacia and - in contrast to all other specieswhen exposed to intraspecific competition and lowest in the mixture with $Q$. robur (Fig. 2, RC). In contrast to the RC treatment, a higher biomass allocation toward the roots as a function of species mixture was not found for the $\mathrm{nRC}$ treatment, except for $Q$. robur (Fig. 2, nRC).

Corresponding to the higher proportion of root biomass, the relative proportions of the leaf and branch biomass of $Q$. robur and $C$. betulus were lower in the mixture with exotic species than in monocultures or in the mixture with the other native species (Table 3). The proportions of the stem biomasses showed no significant difference between the species combinations. 
RC

\section{Quercus robur}

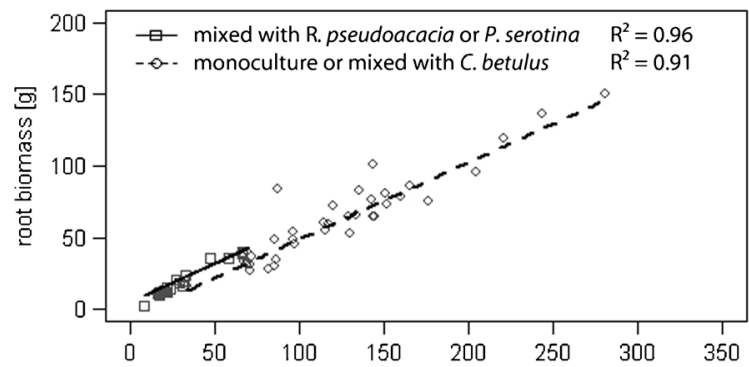

Robinia pseudoacacia

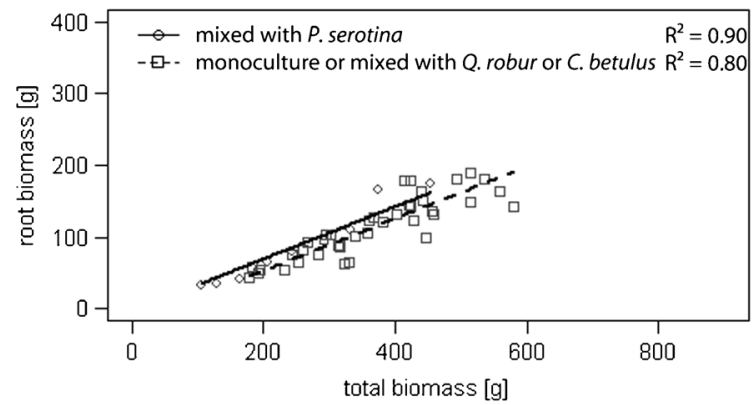

$\mathrm{nRC}$

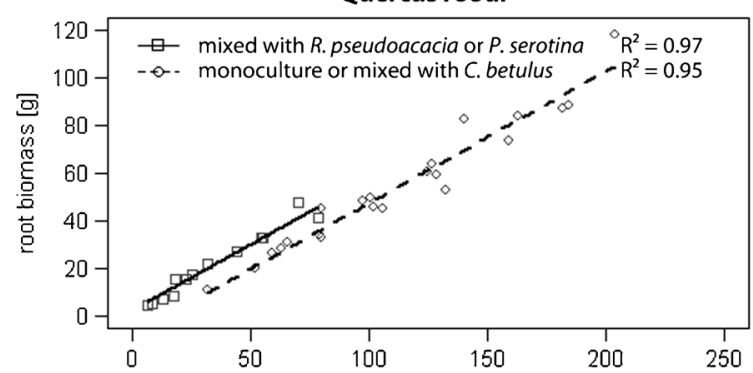

Robinia pseudoacacia

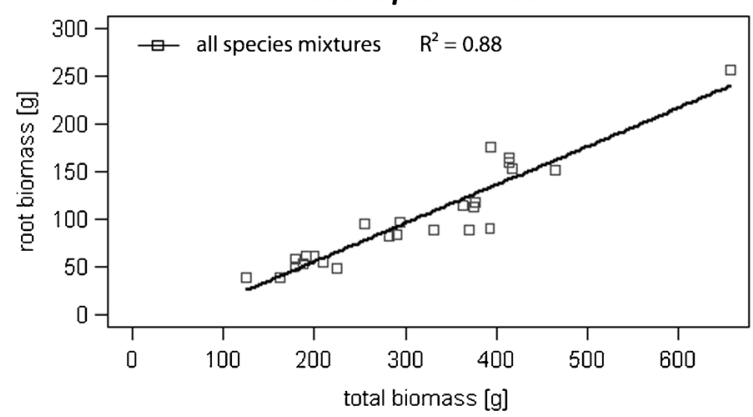

Fig. 2 Allometric relationship between root biomass and total biomass (averaged for each species per pot). Data are given for the different tree species in monoculture and species mixtures with root competition $(R C$, top four figures ) or without root competition ( $n R C$, bottom four figures). Regression lines represent the minimal adequate models derived through

\section{Discussion}

4.1 Exotic species are strong competitors in the seedling phase

Our results revealed that $R$. pseudoacacia and P. serotina exerted a high competitive pressure on the two native species

\section{Carpinus betulus}

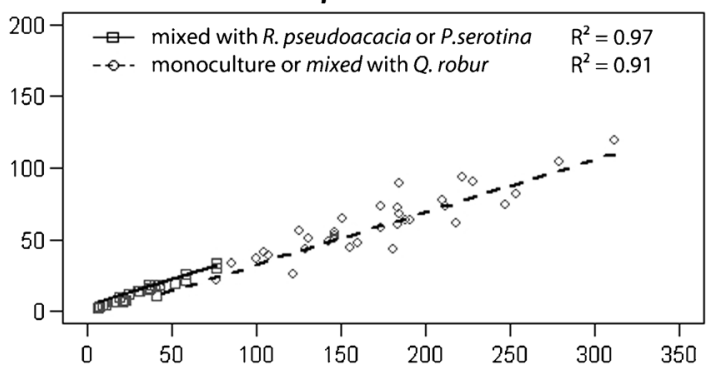

Prunus serotina

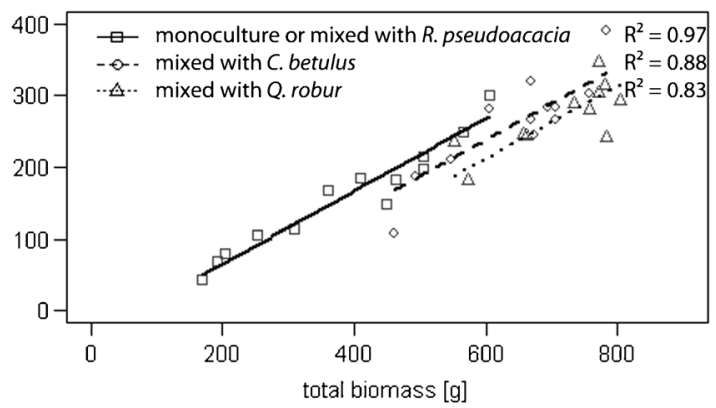

Carpinus betulus

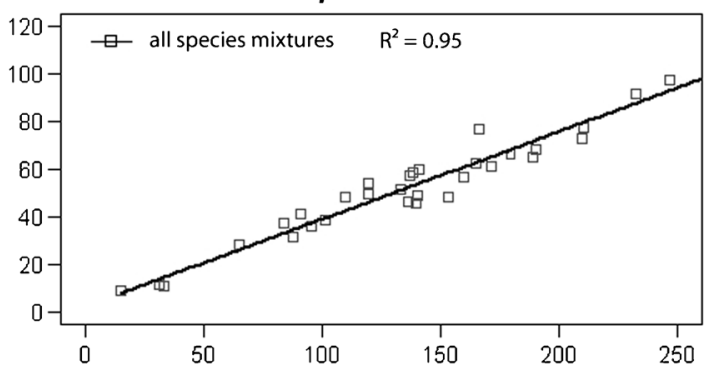

Prunus serotina

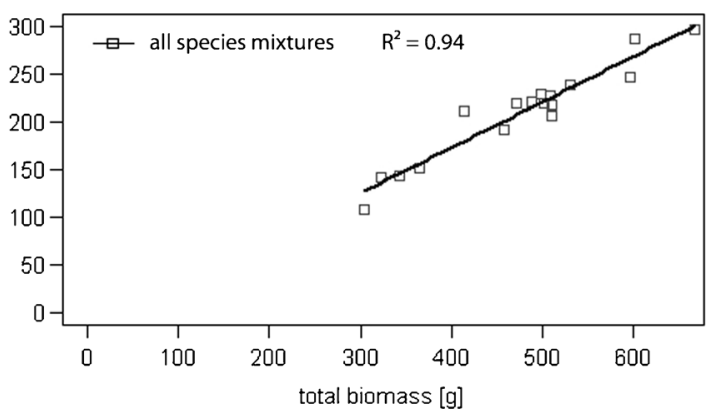

simplification $(P<0.05$ for backward steps $)$ from linear models with interaction of species mixture as the experimental factor (root biomass= factor + total biomass + factor $\times$ total biomass). Only significant regression lines are shown to simplify the figure

(Fig. 1). Besides, the mean relative increment in diameter was highest for P. serotina, whereas $R$. pseudoacacia had the highest mean increment in height (Table 1). Based on the significantly higher growth rates of the two exotic species, the mixture with one of these species resulted in a substantial biomass reduction and altered biomass partitioning of native 
Q. robur and C. betulus (Table 2). Furthermore, our results showed that root competition (RC treatment) had an additional negative effect on the biomass production of both native species (Fig. 2 and Table 2). In the RC treatment, R. pseudoacacia and $P$. serotina occupied most of the available rooting capacity of the pot in mixtures of native and exotic species. By occupying the rooting space that theoretically "belongs" to the less competitive native species, the exotic species most likely had access to additional resources, whereas the resource availability for $Q$. robur and $C$. betulus was restricted.

The high competitiveness and predominance of $R$. pseudoacacia and $P$. serotina in the pot experiment could be explained by their life history traits. Both exotic species are typical early successional species characterized by a rapid growth rate under open field conditions, especially in the seedling stage like in our study (e.g., von Holle et al. 2006; Closset-Kopp et al. 2007). The ability to rapidly deplete a resource turns the exotic species of this study into successful competitors that suppress co-occurring species (e.g., Motta et al. 2009; Closset-Kopp et al. 2011).
4.2 Allocation to root biomass as a sign for competitive stress

One of the most important factors determining the belowground competitiveness of plants is the occupation of soil space (Casper and Jackson 1997). In the pot experiment, both native species in our experiment allocated relatively more biomass to the roots when growing together with one of the exotic species in the RC treatment (Fig. 2, RC, and Table 3). The exotic species had a significantly higher absolute root biomass than $Q$. robur and C. betulus, and correspondingly, they were most likely able to take up a higher amount of nutrients. This could have led to a nutrient deficiency for the co-occurring native species. Hence, the shift in biomass allocation of $Q$. robur and $C$. betulus toward a higher proportion of root biomass could be a reaction to limited belowground resource availability, as suggested in the balanced growth hypothesis (Shipley and Meziane 2002). The higher proportion of root biomass of the two native species was achieved at the expense of reduced leaf and branch biomass (Table 3 ). The interaction of water transport and photosynthesis supports the greater investment into roots. Dry conditions do not only favor

Table 3 Effects of the factors "competition treatments" and "species mixtures" on allocation to the different biomass compartments (in percent)

\begin{tabular}{|c|c|c|c|c|c|c|c|c|c|c|c|}
\hline \multirow[t]{2}{*}{ Species } & \multirow[t]{2}{*}{$\begin{array}{l}\text { Biomass } \\
\text { compartment }\end{array}$} & \multicolumn{3}{|c|}{$\begin{array}{l}\text { Competition } \\
\text { treatment }\end{array}$} & \multirow{2}{*}{$\begin{array}{l}\text { Tree } \\
\text { size }\end{array}$} & \multicolumn{5}{|c|}{ Mixed with } & \multirow{2}{*}{ 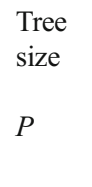 } \\
\hline & & $\mathrm{RC}$ & $\mathrm{nRC}$ & $P$ & & $\begin{array}{l}\text { Quercus } \\
\text { robur }\end{array}$ & $\begin{array}{l}\text { Carpinus } \\
\text { betulus }\end{array}$ & $\begin{array}{l}\text { Robinia } \\
\text { pseudoacacia }\end{array}$ & $\begin{array}{l}\text { Prunus } \\
\text { serotina }\end{array}$ & $P$ & \\
\hline \multirow[t]{5}{*}{ Quercus robur } & Belowground & $54^{\mathrm{a}}$ & $52^{a}$ & 0.219 & $<0.001$ & $49^{a}$ & $49^{\mathrm{a}}$ & $62^{\mathrm{b}}$ & $57^{\mathrm{b}}$ & $<0.001$ & 0.137 \\
\hline & Aboveground & $46^{\mathrm{a}}$ & $48^{a}$ & 0.216 & 0.011 & $51^{\mathrm{a}}$ & $51^{\mathrm{a}}$ & $38^{\mathrm{b}}$ & $43^{b}$ & $<0.001$ & 0.068 \\
\hline & Stem & $22^{\mathrm{a}}$ & $23^{a}$ & 0.715 & 0.821 & $23^{a}$ & $23^{a}$ & $19^{\mathrm{a}}$ & $25^{\mathrm{a}}$ & 0.146 & 0.405 \\
\hline & Branch & $7^{a}$ & $8^{a}$ & 0.257 & $<0.001$ & $9^{a}$ & $9^{a}$ & $4^{b}$ & $6^{\mathrm{ab}}$ & $<0.001$ & 0.364 \\
\hline & Leaf & $17^{\mathrm{a}}$ & $17^{\mathrm{a}}$ & 0.444 & 0.019 & $19^{\mathrm{a}}$ & $19^{\mathrm{a}}$ & $15^{\mathrm{b}}$ & $12^{b}$ & $<0.001$ & 0.075 \\
\hline \multirow[t]{5}{*}{ Carpinus betulus } & Belowground & $39^{a}$ & $39^{b}$ & 0.032 & $<0.001$ & $37^{\mathrm{ab}}$ & $35^{a}$ & $42^{\mathrm{ab}}$ & $45^{b}$ & 0.018 & 0.002 \\
\hline & Aboveground & $61^{a}$ & $61^{\mathrm{b}}$ & 0.032 & $<0.001$ & $63^{a b}$ & $65^{a}$ & $58^{\mathrm{ab}}$ & $55^{\mathrm{b}}$ & 0.018 & 0.002 \\
\hline & Stem & $28^{a}$ & $25^{b}$ & 0.007 & 0.201 & $27^{\mathrm{a}}$ & $27^{a}$ & $28^{a}$ & $25^{\mathrm{a}}$ & 0.338 & 0.273 \\
\hline & Branch & $13^{\mathrm{a}}$ & $15^{\mathrm{a}}$ & 0.890 & $<0.001$ & $15^{\mathrm{a}}$ & $16^{\mathrm{a}}$ & $11^{\mathrm{a}}$ & $13^{\mathrm{a}}$ & 0.175 & $<0.001$ \\
\hline & Leaf & $20^{\mathrm{a}}$ & $21^{\mathrm{a}}$ & 0.914 & 0.030 & $21^{\mathrm{ab}}$ & $22^{a}$ & $19^{\mathrm{bc}}$ & $17^{\mathrm{c}}$ & 0.023 & 0.828 \\
\hline \multirow{5}{*}{$\begin{array}{l}\text { Robinia } \\
\quad \text { pseudoacacia }\end{array}$} & Belowground & $30^{a}$ & $31^{\mathrm{a}}$ & 0.946 & 0.434 & $30^{\mathrm{ab}}$ & $30^{\mathrm{ab}}$ & $29^{\mathrm{a}}$ & $32^{b}$ & 0.017 & 0.588 \\
\hline & Aboveground & $70^{a}$ & $69^{a}$ & 0.949 & 0.356 & $68^{a}$ & $70^{\mathrm{ab}}$ & $72^{b}$ & $68^{a}$ & 0.050 & 0.929 \\
\hline & Stem & $30^{\mathrm{a}}$ & $30^{\mathrm{a}}$ & 0.616 & 0.495 & $30^{\mathrm{ab}}$ & $29^{\mathrm{ab}}$ & $32^{\mathrm{a}}$ & $28^{\mathrm{b}}$ & 0.040 & 0.215 \\
\hline & Branch & $16^{\mathrm{a}}$ & $16^{a}$ & 0.649 & 0.520 & $17^{\mathrm{a}}$ & $18^{\mathrm{a}}$ & $15^{\mathrm{a}}$ & $15^{\mathrm{a}}$ & 0.104 & 0.483 \\
\hline & Leaf & $24^{\mathrm{a}}$ & $23^{a}$ & 0.892 & 0.087 & $20^{\mathrm{a}}$ & $23^{a}$ & $25^{\mathrm{a}}$ & $25^{\mathrm{a}}$ & 0.070 & 0.944 \\
\hline \multirow[t]{5}{*}{ Prunus serotina } & Belowground & $40^{\mathrm{a}}$ & $44^{b}$ & 0.004 & 0.746 & $40^{\mathrm{a}}$ & $40^{\mathrm{a}}$ & $40^{\mathrm{a}}$ & $45^{b}$ & 0.050 & 0.812 \\
\hline & Aboveground & $60^{a}$ & $56^{\mathrm{b}}$ & 0.004 & 0.746 & $60^{a}$ & $60^{\mathrm{a}}$ & $60^{a}$ & $55^{\mathrm{b}}$ & 0.050 & 0.812 \\
\hline & Stem & $22^{\mathrm{a}}$ & $22^{a}$ & 0.162 & 0.091 & $22^{a}$ & $21^{\mathrm{a}}$ & $21^{\mathrm{a}}$ & $22^{\mathrm{a}}$ & 0.483 & 0.190 \\
\hline & Branch & $16^{\mathrm{a}}$ & $14^{\mathrm{b}}$ & 0.039 & $<0.001$ & $17^{\mathrm{a}}$ & $17^{\mathrm{a}}$ & $14^{\mathrm{a}}$ & $15^{\mathrm{a}}$ & 0.566 & 0.107 \\
\hline & Leaf & $22^{\mathrm{a}}$ & $20^{\mathrm{a}}$ & 0.112 & 0.082 & $21^{\mathrm{ab}}$ & $22^{\mathrm{ab}}$ & $25^{\mathrm{a}}$ & $18^{b}$ & $<0.001$ & 0.841 \\
\hline
\end{tabular}

Data are averaged for each species per pot. We adjusted for the effect of tree size as reflected by diameter in the ANCOVA model $\left(\mathrm{biomass}=\right.$ factor $_{\mathrm{a}, \mathrm{b}}+$ tree size). The proportions of biomass compartments are referenced to the average seedling diameter per species. Significant factors and tree size are indicated by $P$ values. Different lowercase letters indicate significant differences between both competition treatments and the different species mixtures (Tukey's test: $P<0.05$ ) 
a reduction in leaf biomass to lower the transpiration rate but simultaneously lead to an increase in root biomass to absorb a higher amount of water (McCarthy and Enquist 2007; Schall et al. 2012). Oliver and Larson (1990) asserted that the allocation of photosynthates to the different biomass compartments proceeds in an order of priorities related to the competitive situation of a tree. In the case of root competition, a greater allocation to the roots is achieved at the expense of a reduced allocation to the leaves and/or the stem (Coomes and Grubb 2000; Murphy and Dudley 2007; Closset-Kopp et al. 2011). That way, plants are able to create a balance between carbon fixation by leaves and nutrient and/or water acquisition by roots (Shipley and Meziane 2002).

In contrast to the native species, the response of the exotic species to belowground competition was less distinct due to their stronger competitiveness. Nevertheless, $R$. pseudoacacia allocated more biomass to the roots when growing together with the competitive P. serotina. These findings may be explained by the second way plants respond to environmental stress, as suggested by the balanced growth hypothesis: not just allocating biomass to the organs acquiring the most limiting resource but increasing uptake efficiency. Actually, the finding that $P$. serotina in monoculture and in mixture and $R$. pseudoacacia in monoculture, though exposed to high competition, had not started changing biomass allocation pattern yet suggests improved resource uptake efficiency. This hypothesis should be investigated in a future experiment. It seems as if the competition by the neighboring plants was not yet strong enough in these mixture types to already initiate changes in biomass allocation.

\subsection{Implications for future work on the invasiveness of exotic tree species}

In order to test the in situ and long-term success of the four species of this study, a factorial experiment, e. g., by exposing planted seedlings in pure and mixed groups to a gradient of canopy openings and/or different soil moisture levels (for instance by trenching), would be needed. However, some beneficial traits of early successional pioneer species are achieved at the expense of other plant attributes (Martin et al. 2010), which might be important under natural conditions. In the Ticino valley for example, flooding occurs quite frequently. In another experiment where we exposed $Q$. robur and $P$. serotina seedlings to flooding and drought and analyzed volatile organic compound emissions, we found that $Q$. robur seedlings appeared to tolerate flood much better than $P$. serotina seedlings (Bourtsoukidis et al. 2013). However, the high tolerance of $Q$. robur seedlings to alterations in soil moisture will only lead to a competitive advantage if light availability is high enough not only to survive but to grow, which may not always be the case under a dense canopy of the exotic species. In contrast to $Q$. robur, C. betulus seedlings, a shade-tolerant species, might be competitive enough to successfully grow in the canopy of the two exotic species.

Acknowledgments We are grateful to K.-H. Heine, A. Parth, M. Unger, T. Waldmann, and U. Westphal and to all other helpers who were a big support while collecting the data.

Funding We would like to thank the Marianne and Dr. Fritz-Walter Fischer Foundation within the Stifterverband für die Deutsche Wissenschaft for funding our research and the DAAD (German Academic Exchange Service) VIGONI program for supporting project-based exchange.

\section{References}

Aerts R, Boot R, van der Aart P (1991) The relation between above- and belowground biomass allocation patterns and competitive ability. Oecologia 87:551-559

Ammer C (2003) Growth and biomass partitioning of Fagus sylvatica L. and Quercus robur L. seedlings in response to shading and small changes in the R/FR-ratio of radiation. Ann For Sci 60:163-171

Annighöfer P, Mölder I, Zerbe S, Kawaletz H, Terwei A, Ammer C (2012) Biomass functions for the two alien tree species Prunus serotina Ehrh. and Robinia pseudoacacia L. in floodplain forests of Northern Italy. Eur J For Res 131:1619-1635

Bloor J, Leadley P, Barthes L (2008) Responses of Fraxinus excelsior seedlings to grass-induced above- and below-ground competition. Plant Ecol 194:293-304

Bourtsoukidis E, Kawaletz H, Radacki D, Schütz S, Hakola H, Hellén H, Noe S, Mölder I, Ammer C, Bonn B (2013) Impact of flooding and drought conditions on the emission of volatile organic compounds of Quercus robur and Prunus serotina. Trees. doi:10.1007/s00468013-0942-5

Cahill JF (2003) Lack of relationship between below-ground competition and allocation to roots in 10 grassland species. J Ecol 91:532-540

Casper BB, Jackson RB (1997) Plant competition underground. Annu Rev Ecol Syst 28:545-570

Closset-Kopp D, Chabrerie O, Valentin B, Delachapelle H, Decocq G (2007) When Oskar meets Alice: does a lack of trade-off in $\mathrm{r} / \mathrm{K}$ strategies make Prunus serotina a successful invader of European forests? For Ecol Manag 247:120-130

Closset-Kopp D, Saguez R, Decocq G (2011) Differential growth patterns and fitness may explain contrasted performances of the invasive Prunus serotina in its exotic range. Biol Invasions 13:1341-1355

Coomes DA, Grubb PJ (2000) Impacts of root competition in forests and woodlands: a theoretical framework and review of experiments. Ecol Monogr 70:171-207

Crawley MJ (2007) The R book. Wiley, Chichester

Curt T, Coll L, Prevosto B, Balandier P, Kunstler G (2005) Plasticity in growth, biomass allocation and root morphology in beech seedlings as induced by irradiance and herbaceous competition. Ann For Sci 62:51-60

DAISIE Project (2009) Handbook of alien species in Europe. Springer, New York, 399 pp

Delagrange S, Messier C, Lechowicz MJ, Dizengremel P (2004) Physiological, morphological and allocational plasticity in understory deciduous trees: importance of plant size and light availability. Tree Physiol 24:775-784

Donald C (1958) The interaction of competition for light and for nutrients. Aust J Agric Res 9:421-435

Ellenberg H (1988) Vegetation ecology of Central Europe, 4th edn. Cambridge University Press, Cambridge 
Feng Y, Wang J, Sang W (2007) Biomass allocation, morphology and photosynthesis of invasive and noninvasive exotic species grown at four irradiance levels. Acta Oecol 31:40-47

Goldberg DE (1990) Components of resource competition in plant communities. In: Grace JB, Tilman D (eds) Perspectives on plant competition. Academic, San Diego, pp 27-49

Haase JU (2009) Biodiversity and ecosystem functioning: the effects of tree and litter diversity. Dissertation, University of Zurich

Hofmann R, Ammer C (2008) Biomass partitioning of beech seedlings under the canopy of spruce. Austrian J For Sci 125:51-66

Horn HS (1971) The adaptive geometry of trees. Princeton University Press, Princeton

Ibrahim L, Proe MF, Cameron AD (1998) Interactive effects of nitrogen and water availabilities on gas exchange and whole-plant carbon allocation in poplar. Tree Physiol 18:481-487

Kawaletz H, Mölder I, Zerbe S, Annighöfer P, Terwei A, Ammer C (2013) Exotic tree seedlings are much more competitive than natives but show underyielding when growing together. J Plant Ecol 6:305-315

Kleczewski NM, Herms DA, Bonello P (2012) Nutrient and water availability alter belowground patterns of biomass allocation, carbon partitioning, and ectomycorrhizal abundance in Betula nigra. TreesStruct Funct 26:525-533

Kleinbauer I, Dullinger S, Peterseil J, Essl F (2010) Climate change might drive the invasive tree Robinia pseudoacacia into nature reserves and endangered habitats. Biol Conserv 143:382-390

Lamarque LJ, Delzon S, Lortie CJ (2011) Tree invasions: a comparative test of the dominant hypotheses and functional traits. Biol Invasions 13:1969-1989

Lorimer CG (1983) Tests of age-independent competition indices for individual trees in natural hardwood stands. For Ecol Manag 6: 343-360

Mack R, Simberloff D, Lonsdale W, Evans H, Clout M, Bazzaz FA (2000) Biotic invasions: causes, epidemiology, global consequences, and control. Ecol Appl 10:689-710

Martin PH, Canham CD, Kobe RK (2010) Divergence from the growthsurvival trade-off and extreme high growth rates drive patterns of exotic tree invasions in closed-canopy forests. J Ecol 98:778-789

McCarthy MC, Enquist BJ (2007) Consistency between an allometric approach and optimal partitioning theory in global patterns of plant biomass allocation. Funct Ecol 21:713-720

McPhee CS, Aarssen LW (2001) The separation of above- and belowground competition in plants a review and critique of methodology. Plant Ecol 152:119-136

Morrison JA, Mauck K (2007) Experimental field comparison of native and non-native maple seedlings: natural enemies, ecophysiology, growth and survival. J Ecol 95:1036-1049

Motta R, Nola P, Berretti R (2009) The rise and fall of the black locust (Robinia pseudoacacia L.) in the "Siro Negri" Forest Reserve
(Lombardy, Italy): lessons learned and future uncertainties. Ann For Sci 66:410-410

Murphy GP, Dudley SA (2007) Above- and below-ground competition cues elicit independent responses. J Ecol 95:261-272

Nilsson U, Albrektson A (1993) Productivity of needles and allocation of growth in young Scots pine trees of different competitive status. For Ecol Manag 62:173-187

Oliver CD, Larson BC (1990) Forest stand dynamics. McGraw-Hill, New York

Pyšek P, Richardson DM (2008) Traits associated with invasiveness in alien plants: where do we stand? Biol Invasions 193:97-125

R Development Core Team (2012) R: a language and environment for statistical computing. R Foundation for Statistical Computing, Vienna, Austria

Rice S, Westerman B, Federici R (2004) Impacts of the exotic, nitrogenfixing black locust (Robinia pseudoacacia) on nitrogen-cycling in a pine-oak ecosystem. Plant Ecol 174:97-107

Schall P, Lödige C, Beck M, Ammer C (2012) Biomass allocation to roots and shoots is more sensitive to shade and drought in European beech than in Norway spruce seedlings. For Ecol Manag 266:246-253

Shipley B, Meziane D (2002) The balanced-growth hypothesis and the allometry of leaf and root biomass allocation. Funct Ecol $16: 326-331$

Starfinger U, Kowarik I, Rode M, Schepker H (2003) From desirable ornamental plant to pest to accepted addition to the flora?-The perception of an alien tree species through the centuries. Biol Invasions 5:323-335

Terwei A, Zerbe S, Zeileis A, Mölder I, Annighöfer P, Kawaletz H, Ammer C (2013) Which are the factors controlling tree seedling establishment in North Italian floodplain forests invaded by nonnative tree species? For Ecol Manag 304:192-203

van Hees AFM (1997) Growth and morphology of pedunculate oak (Quercus robur L.) and beech (Fagus sylvatica L.) seedlings in relation to shading and drought. Ann For Sci 54:9-18

Vanhellemont M, Wauters L, Baeten L, Bijlsma RJ, De Frenne P, Hermy M, Verheyen K (2010) Prunus serotina unleashed: invader dominance after 70 years of forest development. Biol Invasions 12:1113-1124

von Holle B, Joseph KA, Largay EF, Lohnes RG (2006) Facilitations between the introduced nitrogen-fixing tree, Robinia pseudoacacia, and nonnative plant species in the glacial outwash upland ecosystem of Cape Cod, MA. Biodivers Conserv 15:2197-2215

Weiner J (2004) Allocation, plasticity and allometry in plants. Perspect Plant Ecol 6:207-215

Wetterstation Göttingen (2013) http://www.wetterstation-goettingen.de/. Accessed 29 January 2013

Wilson JB (1988) Shoot competition and root competition. J Appl Ecol 25:279-296 